\title{
Online Learning amid the COVID-19 Pandemic: A Case Study of the State Islamic University of Mataram
}

\author{
Azhar \\ State Islamic University of Mataram \\ azhar@uinmataram.ac.id
}

\section{Article History:}

Submitted:

20-10-2020

\section{Accepted:}

20-12-2020

Published:

19-01-2021

\begin{abstract}
:
This research aims to investigate the challenges and opportunities of the use of information technology in an online learning at the State Islamic University of Mataram (UIN Mataram) during the COVID-19 pandemic. This research incorporates a survey to identify the use of information technology among students. The sample used in this research was the first semester students of the State Islamic University of Mataram (UIN Mataram). The research results indicate that $27.3 \%$ of students did not have laptops, $61.8 \%$ of students experienced difficulties accessing the telecommunication signal in their home town, and $10.9 \%$ experienced electricity problems during online learning. The use of Google Classroom and WhatsApp group media is prevalent at the university during the 2020 COVID-19 pandemic.
\end{abstract}

Keywords: Online Learning; Information Technology; the State Islamic University of Mataram (UIN Mataram); the COVID-19 pandemic 


\section{Introduction}

The pandemic of COVID19 has spread to all countries, presenting challenges to all educational institutions, including universities. The government worldwide has banned gathering and required people to practice physical distance. Through the Ministry of Education and Culture (MOEC), the government has mandated universities to conduct online teaching to prevent the spread of COVID-19 (Ministry of Education Circular Decree No. 1 in 2020). ${ }^{1}$ MOEC has published a Ministerial decree to avoid the group gathering that might improve the case of COVID-19 because face-toface learning might attract many students, teachers, and officers to conduct activities at the university. Therefore, teaching and learning should be undertaken in a scenario that prevents physical contact

\footnotetext{
${ }^{1}$ Ali Sadikin, et al., "Pembelajaran Daring di Tengah Wabah COVID-19," BIODIK: Jurnal Ilmiah Pendidikan Biologi 6, no. 2 (2020):

215 , https://doi.org/10.22437/bio.v6i2.9 759
}

between students and teachers. ${ }^{2}$

Many

universities respond quickly to the government decision, including the State Islamic University of Mataram (UIN Mataram), by issuing a letter to prevent the spread of COVID-19 in the university environment. There are 10 points in the decision, and one of the recommendations is to conduct online teaching and learning activities. According to Milman in Farman et al., the use of digital technology allows students and lecturers to be in different places during the learning process. $^{3}$ Online learning is a form of an online teaching strategy that can be used to solve the COVID-19 pandemic. According to Darin E. Hartley, online learning is a form of teaching and learning that allows

2 Fieka Nurul Arifa, “Tantangan Pelaksanaan Kebijakan Belajar Dari Rumah Dalam Masa Darurat COVID-19," INFO Singkat: Kajian Singkat Terhadap Isu Aktual Dan Strategis 12, no. 7 (April 2020): 13.

3 Firman, and Sari Rahayu. "Pembelajaran Online di Tengah Pandemi COVID-19," Indonesian Journal of Educational Science (IJES) 2.2 (2020): 81-89. 
students to distribute learning materials using the Internet, intranet, or other computer networks. ${ }^{4}$

Research conducted by Wahyudin Darmalaksana shows that the pandemic COVID-19 has an impact on online learning during COVID-19. Lecturers' use of digital technologies is in line with the call to become a digital leader in higher education. Despite the challenges posed by the COVID-19 pandemic, higher education institutions could use such challenges to leverage information technologies in teaching. ${ }^{5}$ Online learning is organized to use an electronic system or even a computer to support a learning process. ${ }^{6}$

Online learning requires the support of digital devices

4 Darin E.Hartley, Selling ELearning, American Society for Training and Development. 2001

5 Wahyudin Darmalaksana, et al. "Analisis Pembelajaran Online Masa WFH Pandemic COVID-19 sebagai Tantangan Pemimpin Digital Abad 21." Karya Tulis Ilmiah (KTI) Masa Work From Home (WFH) COVID-19 UIN Sunan Gunung Djati Bandung (2020): 5.

6 Michael Allen, Guide To ELearning, (Canada: John Wiley \& Sons, 2013), 27. such as smartphones, laptops, computers, and tablets with which information can be obtained anytime and anywhere. ${ }^{7} \quad$ Learning activities during the COVID19 pandemic should incorporate online learning. ${ }^{8}$ It is distributed online, communicated online, and tested online. This online learning system is backed by several applications such as Google Classroom, Google Meet, Edmodo, and Zoom. ${ }^{9}$

Information technology can be the solution to online learning, the implementation of the physical distancing policy which becomes the basis for online learning at the university.

The

7 Gikas, J., \& Grant, M. M. "Mobile computing devices in higher education: Student perspectives on learning with cellphones, smartphones \& social media," Internet and Higher Education, 19 (2013): 19, http://dx.doi.org/10.1016/j.iheduc. 2013.06.002

8 Zulkifli, et al., Berkarya Bersama di Tengah COVID-19, (Parepare: IAIN Parerpare Nusantara Press, 2020), 336.

9 Syafni Ermayulis, "Penerapan Sistem Pembelajaran Daring dan Luring di Tengah Pandemi COVID19," Retrieved September 11, 2020, from https://www.stitalkifayahriau.ac.id/ 
implementation of online learning might face some challenges because lecturers and students are not accustomed to online learning .10

Online learning is implemented at the State Islamic University of Mataram (UIN Mataram), which requires all faculty members and students to use digital technology. Lecturers must prepare materials in the form of instructional materials and video tutorials before conducting online lectures. Online learning has not been maximized due to faculty and student readiness, so it needs to be adjusted first. Many students have hurdles to online learning due to a lack of facilities. Signal limitations, limited data packets, and a lack of technology ownership were common among students. Many students who live in rural have difficulty accessing the internet. This indicates

\footnotetext{
${ }^{10} \mathrm{Ni}$ Komang Suni Astini, “Tantangan Dan Peluang Pemanfaatan Teknologi Informasi Dalam Pembelajaran Online Masa COVID-19," Cetta: Jurnal Ilmu Pendidikan 3, no. 2 (2020): 242, https://doi.org/10.37329/cetta.v3i2. 452
}

that online learning faces some challenges. However, there are opportunities to take advantage of information technology that should be developed by the faculty more systematically.

The similar study has been conducted by Chayder Hussain, who found that the use of the internet is still limited to finding information rather than being used as a complete new learning system to improve the learning process's effectiveness and efficiency. ${ }^{11}$ Meanwhile, according to Ace Suryadi, alternatives include educational approaches and information and communication technology (ICT) reforms for education. The school reform should be seen in the context of educational reform. ${ }^{12}$ While

\footnotetext{
11 Husain, Chaidar. "Pemanfaatan teknologi informasi dan komunikasi dalam pembelajaran di SMA Muhammadiyah Tarakan," Jurnal Kebijakan dan Pengembangan Pendidikan 2 no. 2 (2014): 184, https://doi.org/10.22219/jkpp.v2i2. 1917

12 Suryadi, A. "Pemanfaatan Ict Dalam Pembelajaran," Jurnal Pendidikan Terbuka Dan Jarak Jauh, 8, no. 2 (2007): 83. Retrieved from
} 
the study is similar to this study, the COVID-19 situation poses a new challenge for lecturers on maintaining students' psychological condition during distance learning. As such, this study identifies the opportunities and challenges of using information technology in online learning at State Islamic University of Mataram (UIN Mataram) during the COVID-19 pandemic.

\section{Method}

This research incorporates a qualitative method by using survey data collection and library research techniques. Literature research is a study used to gather information and data in a library using various materials such as documents, books, magazines, historical stories, and news. ${ }^{13}$

In this study, data collection was obtained from news and articles in online journals by using the keywords "Impact of COVID-
19", "Online Learning". Survey research was conducted by disseminating questionnaires using Google Form. The primary data collection of this study by distributing questionnaires to respondents. ${ }^{14}$

The respondents of this study were 110 students of the State Islamic University of Mataram (UIN Mataram) Semester 1 from the department of Islamic Education, the Department of English Language Teaching, the Department of Early Childhood Education, and the Department of Biological Education. The data collected from various ways of collecting the data is then processed and combined to obtain interpretation related to the challenges and opportunities of the utilization of information technology in online learning activities during the COVID19 pandemic. http://jurnal.ut.ac.id/index.php/jpt jj/article/view/537

13 Sugiyono, Memahami Penelitian Kualitatif, (Bandung: Alfabeta, 2012), 76.
14 Creswell, John W. Research design pendekatan kualitatif, kuantitatif, dan mixed. (Yogyakarta: Pustaka Pelajar, 2014), 165. 


\section{Result and Discussion}

The policy of implementing online learning in all Indonesian universities is to prevent the increase of COVID-19. The Ministry of Education and Culture (MOEC) of the Republic of Indonesia encourages the implementation of online learning processes. In response to the coronavirus outbreak in March, 2020, MOEC published a policy on Prevention of Coronavirus Disease (COVID19) in Educational Units through the circular letter No. 35492 / A.A5 / HK / 2020 from the Secretary-General of the Ministry of Education.

The implementation of the physical distance policy became the basis for online learning during the COVID-19 pandemic has shocked the lecturers and students because they were not accustomed to online learning. Some lecturers were surprised that they needed to incorporate digital technologies in their teaching fully. The findings around the dynamics of online learning are as follows.

\section{Challenges of Utilizing Information Technology in Online Learning}

According to the questionnaire data of online learning during the COVID-19 pandemic, many students at State Islamic University of Mataram (UIN Mataram) are still not ready for online learning in terms of the technology infrastructure. This can be seen from the following data:

\section{Table 1 Student Challenges}

\begin{tabular}{|c|l|c|}
\hline No. & \multicolumn{1}{|c|}{ Aspect } & $\begin{array}{c}\text { Percentage } \\
\text { of students }\end{array}$ \\
\hline 1. & $\begin{array}{l}\text { Do not have } \\
\text { digital } \\
\text { devices (HP, } \\
\text { smartphones, } \\
\text { laptops, } \\
\text { tablets, etc.) }\end{array}$ & $61,8 \%$ \\
\hline 2. & $\begin{array}{l}\text { Inadequate } \\
\text { internet } \\
\text { network }\end{array}$ & $10,9 \%$ \\
\hline 3. & $\begin{array}{l}\text { Inadequate } \\
\text { power grid }\end{array}$ & \\
\hline
\end{tabular}

Based on the table above data, $27.3 \%$ of students reported that they did not have a laptop computer. This data shows that there were still many students who had not participated much in online learning. 
The students' geographical location also causes challenges for online learning at the university. Most of the students resided in rural areas, making it difficult for many students to access the Internet. The survey results showed that $61.8 \%$ of students experienced signal problems and wasted their data as they could barely used it. Moreover, 10.9\% of students experienced improper electrical network restrictions when participating in an online learning. This is an important issue for the establishment of the online learning at the State Islamic University Mataram (UIN Mataram). Many students rely on subsidized administration fees because they did not know when the lectures would return to normal.

According to the 2020 Ministry of Education Circular No. 1 on the prevention of the spread of coronavirus (COVID19) in universities states that the university needs to: "Organize distance learning according to criteria. Synchronous and asynchronous online training via platforms such as Google Classroom, Edmodo, Schoology, Classdojo (for kids), video form material recording:
Camtasia, Screencast-O-Matic, Use Seesaw, Xrecorder, and training Quizlet, Quiziz, or Kahoot".

Based on the circular, the lecture system at State Islamic University of Mataram (UIN Matram) is delivered via remote lectures using Google Classroom Platform, Edmodo, Adlink, Scholastic, Zoom, and WhatsApp group. Online learning applications based on usage survey results show that the most used applications from the State Islamic University of Mataram (UIN Matram) lecturers and students were Google Classroom (45\%), WhatsApp groups (30\%), Schooling Max (15\%), Edmodo (5\%), Adlink (3\%), and Zoom $(2 \%)$. The use of Google Classroom and WhatsApp group media were high among lecturers and students of State Islamic University of Mataram (UIN Mataram) because they were easy to understand and students could access it freely. To make the lecture more interesting to students and understand from the students' material, lecturers necessitated to teach creativity to their respective lecturers, such as interpreting the subject, using video conferencing, or other 
applications for zooming in with interactive content.

\section{Opportunities for}

Utilization of Information

Technology in Online

\section{Learning}

The digital transformation of the education sector in Indonesia is not a new discourse for practitioners and policymakers, supporting regulations and substantial efforts to implement digital transformation in the higher education environment and for all. Previously various discourses around digital technologies failed to ensure that the education sectors especially universities, secondary schools, polytechnics, academies, primary and secondary schools are making significant progress. In the digital transformation of Indonesian education, COVID-19 had a huge potential to leverage the use of digital technologies in education. ${ }^{15}$

The COVID-19 is a disaster that has a negative impact on

15 Masrul, et al., Pandemik COVID-19 [sumber elektronis]: persoalan dan refleksi di Indonesia, (Kota Medan: Yayasan Kita Menulis, 2020), 64 . almost all areas of human life-major social restriction efforts (PSBB) to prevent the spread of COVID-19, work from home, and study from home. However, it cannot be denied that the the COVID-19 pandemic had some positive effects to accelerate Indonesia's digital transformation process.

All Indonesian universities and schools, including State Islamic University of Mataram (UIN Mataram), have stopped teaching face-to-face. However, Pandemic COVID-19 should not definitely stop the learning process. Today, everyone needs to conduct online learning. Currently, lecturers, teachers, students, and alumni use various tools for online learning. However, it can face different obstacles and different limitations. In any case, it is an initiative that need to be supported by policy makers and practitioners at the University.

Webinar was also prevalent during the COVID-19 pandemic. It is a seminar held using internet applications such as Zoom, Google Meet, and Jitsi. Through webinars, it is possible to discuss many issues without distance or space constraints. Many lecturers and educators were 
hosting web conferencing to prevent COVID-19 spread in Indonesia, so many web conferencing is being held, including several instructors from the State Islamic University of Mataram (UIN Mataram). There were paid web conferencing, many of which offer high-quality web conferencing for free. This is arguably one indicator of the positive development of the digital transformation of education in Indonesia during the information technology platforms are likely to be used to support online learning activities and at the same time encourage lecturers to master information technology, some of which are: e-learning, home learning, Edmodo, EdLink, Moodle, Google Classroom, WhatsApp, and Schoology.

WhatsApp is best known among students and lecturers of the State Islamic University of Mataram (UIN Mataram). This is due to the fact that before the COVID-19 pandemic, students and lecturers also actively communicated and interacted during the learning process through the WhatsApp group. However, during this pandemic, educators use online learning to develop digital skills, and teachers use a more comprehensive range of digital modes to allow students to explore and absorb information related to the material. This can be seen that the use of familiar digital technology tool such as WhatsApp could support the continuation of learning during the COVID-19 pandemic.

\section{Conclusion}

The COVID-19 pandemic has profoundly affected higher education in Indonesia, including the State Islamic University of Mataram (UIN Mataram). The university implemented a physical distance policy, which then becomes the basis for the implementation of online learning, using information technologies such as WhatsApp Group, Edmodo, EdLink, Moodle, Google Classroom, and School Schoology. The most common tool used for online learning at the State Islamic University of Mataram (UIN Mataram) is WhatsApp Group and Google Classroom.

However, some things are challenging such as inadequate features of 
technology tools. Based on the survey results, $27.3 \%$ of students did not have a laptop, $61.8 \%$ of students said it was difficult to get proper telecommunication signal. $10.9 \%$ students had an electricity ptoblem during online learning. Many students lived far away from urban areas. They believe that online lecturing is ineffective because they are not accustomed to participating in online learning. Despite having a negative impact on teaching and learning, COVID-19 leveraged educational institutions' opportunities to improve digital technology transformation through online learning.

\section{Bibliography}

Ali Sadikin, et al., "Pembelajaran Daring di Tengah Wabah COVID19 (Online learning amids the COVID-19 pandemic)," BIODIK: Jurnal Ilmiah Pendidikan Biologi 6, no. 2 (2020): 215,

https://doi.org/10.2243

7/bio.v6i2.9759

Creswell, John W. Research design pendekatan kualitatif, kuantitatif, dan mixed (Research Design: Qualitative, Quantitative, and Mixed Methods Approaches). (Yogyakarta: Pustaka Pelajar, 2014), 165.

Darin E.Hartley, Selling ELearning, American Society for Training and Development. 2001 Fieka Nurul Arifa, “Tantangan Pelaksanaan Kebijakan Belajar Dari Rumah Dalam Masa Darurat COVID-19 (Challenges of implementing learning from home in the COVID-19 pandemic)," INFO Singkat: Kajian Singkat Terhadap Isu Aktual Dan Strategis 12, no. 7 (April 2020): 13.

Firman, and Sari Rahayu. “Pembelajaran Online di Tengah Pandemi COVID-19 (Online learning during the COVID-19)," Indonesian Journal of Educational Science (IJES) 2.2 (2020): 81-89.

Gikas, J., \& Grant, M. M. "Mobile computing devices in higher education: Student perspectives on learning with cellphones, 
smartphones \& social media," Internet and Higher Education, 19 (2013):

http://dx.doi.org/10.10

16/j.iheduc.2013.06.002

Husain, Chaidar.

"Pemanfaatan teknologi informasi dan komunikasi dalam pembelajaran di SMA Muhammadiyah

Tarakan (Use of Information Technology at SMA Muhammadiyah Tarakan)," Jurnal Kebijakan dan

Pengembangan

Pendidikan 2 no. 2 (2014): 184 ,

https://doi.org/10.2221

9/jkpp.v2i2.1917

Masrul, et al., Pandemik COVID-19:persoalan dan refleksi di Indonesia [sumber elektronis] (Pandemic Covid-19: Challenges and Reflections for Indonesia) , (Kota Medan: Yayasan Kita Menulis, 2020), 64.

Michael Allen, Guide To ELearning, (Canada: John Wiley \& Sons, 2013), 27.

Ni Komang Suni Astini, “Tantangan Dan Peluang Pemanfaatan Teknologi
Informasi

Dalam

Pembelajaran Online

Masa COVID-19

(Challenges and Opportunities using Information Technology in the Online Learning during the COVID-19)," Cetta: Jurnal Ilmu Pendidikan 3, no. 2 (2020): 242 , https://doi.org/10.3732

9/cetta.v3i2.452

Sugiyono,

Memahami

Penelitian Kualitatif

(Understanding

Qualitative Research),

(Bandung: Alfabeta, 2012), 76.

Suryadi, A. "Pemanfaatan ICT Dalam Pembelajaran (Uses of ICT in teaching and Learning)," Jurnal Pendidikan Terbuka Dan Jarak Jauh, 8, no. 2 (2007):

83. http://jurnal.ut.ac.id/in dex.php/jptjj/article/vie $\mathrm{w} / 537$

Syafni Ermayulis, "Penerapan Sistem Pembelajaran Daring dan Luring di Tengah Pandemi COVID-19 (The implementataion of Online Learning in the COVID-19 Pandemic)," Retrieved September 11, 2020, from 
Azhar.

https://www.stit-

alkifayahriau.ac.id/

Wahyudin Darmalaksana, et

al.

"Analisis

Pembelajaran Online

Masa WFH Pandemic

COVID-19 sebagai

Tantangan Pemimpin

Digital Abad 21 (The

Analysis of Online

Learning in the COVID-

19 pandemic as a challenge for 21st century Learning)." Karya Tulis Ilmiah (KTI) Masa Work From Home (WFH) COVID-19 UIN Sunan Gunung Djati Bandung (2020): 5.

Zulkifli, et al., Berkarya Bersama di Tengah COVID-19 (Working in the COVID-19 Pandemic), (Parepare: IAIN Parerpare Nusantara Press, 2020), 336. 
